\title{
Ownership and performance in water services revisited: Does private management really outperform public?
}

\author{
Marta SUÁREZ-VARELA * \\ María de los Ángeles GARCÍA-VALIÑAS ** \\ Francisco GONZÁLEZ-GÓMEZ *** \\ Andrés J PICAZO-TADEO *,1 \\ * Universidad de Valencia, Spain \\ ** Universidad de Oviedo, Spain \\ *** Universidad de Granada, Spain \\ ${ }^{1}$ Corresponding author: andres.j.picazo@uv.es
}

\begin{abstract}
Since the late 1970s, water services have been privatised in some developed countries in an attempt to improve performance. However, after three decades of privatisations the superiority of private management is being questioned and several cities are returning to public provision. In this paper we revisit the relationship between ownership and performance in urban water services management using directional distance functions, metafrontiers and Data Envelopment Analysis techniques. The performance in the provision of water delivery services in 70 Spanish municipalities is assessed at the level of the management of specific production factors; moreover, we discuss whether differences in efficiency between private and public decision units are due to either different capabilities of managers (managerial efficiency) or different technological restrictions (ownership efficiency). Our main finding is that private management is more efficient in the use of labour input, mainly because of the technological restrictions faced by public management units, such as legal and institutional restrictions. Conversely, private management appears to be less efficient at managing operational costs.
\end{abstract}

Keywords. Urban water services; ownership; performance; technological restrictions; Spain.

JEL Classification. C6; L25; L95.

\section{Introduction}

Economic performance is a common focus of study in both theoretical and empirical economics. Particularly, there is a growing interest in developing and implementing accurate performance measures for the water sector, and so providing useful information to a number of relevant stakeholders, from managers of utilities, to regulatory bodies and policymakers, thus enabling them to make more informed decisions on which practices and regulations favour the industry. Moreover, the issue of the relationship between ownership and performance has also long stood at the core of the debate in the water industry. 
Water is a merit good that serves economic, environmental and social purposes (OECD, 2003), and displays important positive externalities. It is also a human need, so universal access should be guaranteed. Moreover, the water industry faces high fixed costs and is very capital intensive with high initial investment required, conditions which lead to a natural monopoly. Accordingly, thorough supervision and intervention on behalf of the public sector is justified as a means of preventing market failure, achieving an efficient allocation of resources and guaranteeing that welfare standards are met (Pigou, 1932). In fact, public provision has typically been the most common form of water services provision.

However, following the wave of deregulation of economic activity that started in AngloSaxon economies in the late 1970s, private sector participation in the water industry became increasingly popular and nowadays it is widespread in some developed countries. ${ }^{1}$ Deregulation was based on the idea that, far from pursuing the general interest, public intervention works to satisfy political interests (Niskanen, 1971); accordingly, privatising water provision and introducing competition via tendering processes should promote efficiency and cost reduction. In addition, privatisation would allow the aggregation of demand, particularly in small-sized municipalities, thus achieving a more efficient scale of production (Donahue, 1989). But, after more than three decades of privatisations, and without any conclusive empirical evidence as to the superiority of private management of urban water services over public management, the option to privatise is being questioned and several cities are moving back to public provision.

Against this background, this paper revisits the relationship between ownership and performance in water management using a fresh methodological approach based on directional distance functions, metafrontiers and Data Envelopment Analysis (DEA) techniques. Our contribution to existing literature in this field is twofold. On the one hand, we assess performance at the level of the management of specific production factors; on the other hand, and more interestingly, we discuss whether differences in performance between private and public management units are due to different capabilities of managers (managerial efficiency) or rather to different technological restrictions faced by the two types of management (ownership efficiency). In our empirical analysis, we use in-

\footnotetext{
1 See Pérard (2009) for figures on private sector participation in water supply in OECD countries.
} 
formation about the provision of the service of water delivery in 70 Spanish municipalities. Our main finding is that private management is more efficient in the use of labour, mainly because of technological restrictions faced by public management units, i.e., legal and institutional restrictions.

The remainder of the paper is organised as follows. Section 2 briefly reviews the empirical literature on ownership and performance in the provision of water services. Section 3 presents the data and explains the methodology. Section 4 describes and discusses the results, while a final section summarises and concludes.

\section{Ownership and performance in water utilities: Some empirical evidence}

Research on the effects of privatisation on the efficiency of water services management dates back to the 1970s, with the seminal works by Mann \& Mikesell (1976), Morgan (1977) and Crain \& Zardkoohi (1978). Those first studies focused on the water industry in the Unites States and, since then, this issue has been the subject of increasing attention. By the end of the eighties only around thirty papers had been published, whereas in the nineties alone about forty studies were conducted, and by 2010 there were well over 250 publications (Berg \& Marques, 2011; Carvalho et al., 2012). Moreover, the initial geographical focus quickly spread to areas with markedly different contexts, so that case studies can now be found from the five continents, and from both developing and developed economies.

Empirical studies addressing differences in efficiency between publicly and privately managed urban water services are mainly divided into two groups: studies exploring the trends in main performance indicators after the implementation of a privatisation process; and cross-sectional studies based on comparisons of performance indicators between public and private management units. Most studies in the first group focus on the massive privatisation process of the water industry witnessed in the United Kingdom at the end of the 1980s and they mainly found that privatisation did not lead to increased efficiency in urban water services. ${ }^{2}$ Conclusions from the second group of studies are more diverse and even contradictory. Table 1 shows a selection of empirical studies.

\footnotetext{
${ }^{2}$ An exception is the paper by Estache \& Trujillo (2003) that, using information from four utilities in Argentina between 1992 and 2001, found that privatisation led to important gains in total fac-
} 
Among those papers that find public management of urban water services to be superior, several explanations are adduced, such as lower costs (Mann \& Mikesell, 1976; Bruggink, 1982; Bhattacharyya et al., 1995a) or better results in a range of performance indicators (Benito et al., 2010; Romano \& Guerrini, 2011; Guerrini, 2011; Da Cruz et al., 2012; Romano et al., 2013; Lannier \& Porcher, 2014). Other studies find that public companies are also more efficient at achieving social and development goals (Lobina \& Hall, 2000). Regarding analyses that found private management to be superior in terms of performance, reasons given include lower costs (Morgan, 1977; Crain \& Zardkoohi, 1978) and higher technical efficiency (Picazo-Tadeo et al., 2009a, 2009b). In addition, some of these papers maintain that differences in efficiency exist mainly in labour management (Crain \& Zardkoohi, 1978; Picazo-Tadeo et al., 2009a, 2009b). Nevertheless, a majority of studies either find no significant difference between the performance of public and private water suppliers or reach no definite conclusion. Furthermore, some papers point out that once characteristics of the operating environment are accounted for, differences in efficiency diminish (Saussier \& Menard, 2000; González-Gómez et al., 2013).

Regarding the methodological approach employed to assess efficiency, until the beginning of the 21st century there was a predominance of parametric techniques using cost (Mann \& Mikesell, 1976; Morgan, 1977; Bruggink, 1982; Feigenbaum \& Teeples, 1983; Bhattacharyya et al., 1994) and production (Crain \& Zardkoohi, 1978) functions, and/or Stochastic Frontier Analysis (SFA). However, most studies these days are based on estimates of non-parametric frontiers and performance indicators by means of Data Envelopment Analysis (DEA) techniques, with only a few studies using other techniques (Byrnes et al., 1986; Saal \& Parker, 2001; Lobina \& Hall, 2000; Estache \& Trujillo, 2003).

On the other hand, performance differences between public and private management units have been evaluated using two main methodological approaches. The first consists of using ANOVA, Mann-Whitney, Kolmogorov-Smirnov or Kruskal-Wallis tests, among others, to test for differences in efficiency score means obtained from either DEA-based analyses or cost and production function estimates with SFA. The second approach relies on directly including dummy variables reflecting ownership in the estimation of cost

tor productivity. However, as pointed out by the authors, this result should be interpreted with caution given the small size of the sample employed. 
and production functions with SFA, or including them in second- or third-step regression analyses of DEA-based efficiency scores.

\section{Data, variables and methodology}

\subsection{Data and sample}

In this paper we use data relating to the provision of the service of urban water delivery ${ }^{3}$ in 70 Spanish municipalities of under 50,000 inhabitants. In 37 of these municipalities either the city council itself or a public utility manages water delivery (public management units), while in the other 33 cases the service is privately managed by either a contractual public-private partnership (PPP) or an institutionalised PPP (private management units). ${ }^{4}$ The data, which correspond to 2013, were collected, when available, from web pages of municipalities and utilities as well as by direct contact with city councils and utilities' managers, in the framework of a wider project supported and financed by the Spanish Ministry of Economy and Competitiveness. ${ }^{5}$

Two outputs and three inputs are used to characterise the productive process of both public and private decision units. The two outputs are water delivered and population served. Of the three inputs, one is fixed - the length of the delivery network -, and two are variable - labour and operational $\operatorname{costs}^{6}$ (see Picazo-Tadeo et al., 2008). Table 2 provides measurement units and some descriptive statistics for the data.

\footnotetext{
${ }^{3}$ In addition to water delivery, some water utilities in Spain also provide the service of sewage treatment; however, this is not the case of the utilities in our sample.
}

${ }^{4}$ García-Valiñas et al. (2013) provides a detailed description of legal forms for the management of urban water services in Spain. Furthermore, following previous literature, institutionalised PPPs have been considered as private management units given that day-to-day management is carried out by the private partner (see García-Valiñas et al., 2013; Picazo-Tadeo et al., 2012). Finally, it is worth mentioning that in compliance with Spanish laws only the management of the urban water service can be privatised, while infrastructures always remain under public property.

${ }^{5}$ According to Spanish legislation, data on inputs and outputs of water suppliers are not made public. When elaborating our database, we submitted information requests to nearly 1,000 Spanish municipalities, either via web pages or directly to city councils and utilities. Of these, we received 141 positive responses. After deleting observations with deficient or incomplete information, we selected 70 decision units that are dedicated only to water service delivery.

${ }^{6}$ Operational costs include all expenses required for day-to-day management of the service, e.g., raw water, chemicals employed to make water suitable for human consumption, energy and office expenses, among others; conversely, wages and other labour costs are excluded. Furthermore, the canon paid by utilities to the local government at the moment of being awarded with the contract for the management of the service is also excluded from operational costs. 


\subsection{Methodological issues}

\subsubsection{The metatechnology and the group technology}

Our methodological approach is based on Sáez-Fernandez et al. (2012), which uses directional distance functions (Chambers et al., 1998) to extend the metafrontier approach by O'Donnell et al. (2008) to the measurement of technological differences in the management of specific inputs. ${ }^{7}$ Let us thus assume that our $\mathrm{k}=1 \ldots 70$ decision units use the set of inputs $x=\left(x_{f}, x_{v}\right)$, where the fixed input $x_{f}$ is the length of the delivery network, and variable inputs $x_{v}$ are labour and operational costs, to produce the vector of outputs $y$, which includes water delivered and population served. Transformation of inputs into outputs requires the use of a metatechnology that is represented by the short-run input requirement set. This set includes all combinations of variable inputs $\mathrm{x}_{\mathrm{v}}$ that, given an endowment of the fixed input $\mathrm{x}_{\mathrm{f}}$, allow producing at least a level of outputs $\mathrm{y}$, and it is formally defined as:

$$
\mathrm{L}\left(\mathrm{x}_{\mathrm{f}}, \mathrm{y}\right)=\left[\mathrm{x}_{\mathrm{v}} \mid(\mathrm{x}, \mathrm{y}) \in \mathrm{T}\right]
$$

where $\mathrm{T}$ represents all combinations of inputs and outputs attainable with the present state of knowledge. It is assumed that the metatechnology satisfies the standard properties suggested by Shephard (1970).

Our next building block is the directional metadistance function defined as (Färe \& Grosskopf, 2000):

$\mathrm{MD}=\left[\mathrm{x}, \mathrm{y} ; \mathrm{g}=\left(-\mathrm{g}_{\mathrm{x}_{\mathrm{v}}}, \mathrm{g}_{\mathrm{y}}\right)\right]=\operatorname{Sup}\left\langle\delta \mid\left(\mathrm{x}_{\mathrm{v}}-\delta \mathrm{g}_{\mathrm{x}_{\mathrm{v}}}\right) \in \mathrm{L}\left[\mathrm{x}_{\mathrm{f}},\left(\mathrm{y}+\delta \mathrm{g}_{\mathrm{y}}\right)\right]\right\rangle$

with $g=\left(-\mathrm{g}_{\mathrm{x}_{\mathrm{v}}}, \mathrm{g}_{\mathrm{y}}\right)$ being the so-called direction vector.

This function has a lower bound of zero (other properties are in Chambers et al., 1998), and models inputs and outputs jointly by seeking the maximum attainable expansion of outputs in the $g_{y}$ direction and the largest feasible contraction of variable inputs in the $-\mathrm{g}_{\mathrm{xv}}$ direction. Furthermore, the directional metadistance function is a very flexible tool

\footnotetext{
7 See Beltrán-Esteve (2013), Beltrán-Esteve et al. (2014) and Picazo-Tadeo et al. (2014) for recent empirical applications of this approach.
} 
for assessing efficiency as it allows the technological frontier to be approached via alternative paths which focus on different facets of performance (Picazo-Tadeo et al., 2012).

If we were interested in assessing the maximum proportional (radial) feasible reduction of variable inputs labour and operational costs, given the endowment of the fixed input delivery network and also maintaining the level of outputs, the directional metadistance function would be:

$\mathrm{MD}_{\text {radial }}=\left[\mathrm{x}, \mathrm{y} ; \mathrm{g}_{\text {radial }}=\left(-\mathrm{x}_{\mathrm{v}}, 0\right)\right]=\operatorname{Sup}\left[\delta_{\text {radial }} \mid\left(1-\delta_{\text {radial }}\right) \mathrm{x}_{\mathrm{v}} \in \mathrm{L}\left(\mathrm{x}_{\mathrm{f}}, \mathrm{y}\right)\right]$

Furthermore, it might be of interest to assess potential reduction of variable input i, either labour or operational costs, while maintaining the other input -i, always for given fixed input and outputs, i.e., assessing technical efficiency in the management of variable input $\mathrm{i}$. In this scenario, the directional metadistance function becomes:

$$
\mathrm{MD}_{\mathrm{i}}=\left\langle\mathrm{x}, \mathrm{y} ; \mathrm{g}_{\mathrm{i}}=\left[\left(-\mathrm{x}_{\mathrm{v}_{\mathrm{i}}}, 0_{\mathrm{v}_{-i}}\right), 0\right]\right\rangle=\operatorname{Sup}\left\langle\delta_{\mathrm{i}} \mid\left[\left(1-\delta_{\mathrm{i}}\right) \mathrm{x}_{\mathrm{v}_{\mathrm{i}}}, \mathrm{x}_{\mathrm{v}_{-i}}\right] \in \mathrm{L}\left(\mathrm{x}_{\mathrm{f}}, \mathrm{y}\right)\right\rangle
$$

The directional distance functions of expressions (3) and (4) can also be computed with respect to the technology of each of the two groups of management units considered in this research, namely, public management units and private management units. Accordingly, the technology of group $\mathrm{h}$ (with $\mathrm{h}=$ public, private) is based only on observations of decision units within this group, and can also be represented by the short-run input requirement set defined as:

$$
\mathrm{L}^{\mathrm{h}}\left(\mathrm{x}_{\mathrm{f}}, \mathrm{y}\right)=\left[\mathrm{x}_{\mathrm{v}} \mid(\mathrm{x}, \mathrm{y}) \in \mathrm{T}^{\mathrm{h}}\right]
$$

with $\mathrm{T}^{\mathrm{h}}$ representing all the combinations of inputs and outputs attainable by decision units in group h, i.e., the state of knowledge for units in that group. The key issue here is that some productive plans, i.e., combinations of inputs and outputs, included in the metatechnology may not be possible given the technology of a particular group. 
The directional distance functions computed with respect to the technology of group $\mathrm{h}$ in the case of radial and specific reduction of inputs are, respectively: ${ }^{8}$

$$
\overrightarrow{\mathrm{D}}_{\text {radial }}^{\mathrm{h}}=\left[\mathrm{x}, \mathrm{y} ; \mathrm{g}_{\text {radial }}=\left(-\mathrm{x}_{\mathrm{v}}, 0\right)\right]=\operatorname{Sup}\left[\delta_{\text {radial }}^{\mathrm{h}} \mid\left(1-\delta_{\text {radial }}^{\mathrm{h}}\right) \mathrm{x}_{\mathrm{v}} \in \mathrm{L}^{\mathrm{h}}\left(\mathrm{x}_{\mathrm{f}}, \mathrm{y}\right)\right]
$$

and,

$$
\vec{D}_{i}^{h}=\left\langle x, y ; g_{i}=\left[\left(-x_{v_{i}}, 0_{v_{-i}}\right), 0\right]\right\rangle=\operatorname{Sup}\left\langle\delta_{i}^{h} \mid\left[\left(1-\delta_{i}^{h}\right) x_{v_{i}}, x_{v_{-i}}\right] \in L^{h}\left(x_{f}, y\right)\right\rangle
$$

Figure 1 provides a graphical illustration of our directional functions. Let us assume that we observe a set of six private management units represented by dots, and another set of four public management units identified by crosses. The short-run metatechnology or joint technology is represented by the lower envelopment of all these observations regardless of their private or public character, i.e., the isoquant represented by the continuous line. Similarly, the technologies of private and public units are represented by the dotted and dashed isoquants, respectively. Projecting the inefficient public unit, i.e., that located in the interior of the input requirement set, onto the metatechnology with a direction that reduces both labour and operational costs simultaneously yields point A; furthermore, projection onto the technology of the group of public units would yield point B. Accordingly, the segment BA measures the distance that separates the technology of public units from the metatechnology evaluated at this projection, i.e., the metatechnology ratio. Similarly, the segment DC measures the distance that separates the public technology from the metatechnology, assessed in a direction that reduces input labour whilst operational costs are maintained.

\subsubsection{Technical efficiency and metatechnology ratios}

In order to compute the metatechnology ratios proposed by O'Donnell et al. (2008) it is highly convenient to define the following measures of radial technical efficiency with respect to the metatechnology and the technology of group $h$, respectively: ${ }^{9}$

\footnotetext{
${ }^{8}$ By construction, directional distance functions computed relative to the technology of group $\mathrm{h}$ will always be equal to or lower than directional metadistance functions computed with respect to the metatechnology.

${ }^{9}$ Although directional metadistance/distance functions can be directly interpreted as measures of technical efficiency, metatechnology ratios for efficient management units could not be defined since distances for these observations are equal to zero (Sáez-Fernández et al., 2012).
} 
Techical efficiency $\mathrm{radial}=\left\langle 1-\mathrm{MD}_{\text {radial }}\left[\mathrm{x}, \mathrm{y} ; \mathrm{g}_{\text {radial }}=\left(-\mathrm{x}_{\mathrm{v}}, 0\right)\right]\right\rangle=\left(1-\delta_{\text {radial }}\right)$

and,

Techical efficiency $\mathrm{radial}^{\mathrm{h}}=\left\langle 1-\overrightarrow{\mathrm{D}}_{\text {radial }}^{\mathrm{h}}\left[\mathrm{x}, \mathrm{y} ; \mathrm{g}_{\text {radial }}=\left(-\mathrm{x}_{\mathrm{v}}, 0\right)\right]\right\rangle=\left(1-\delta_{\text {radial }}^{\mathrm{h}}\right)$

These measures are upper-bounded to one - a score that indicates full efficiency - and can be interpreted as conventional Farrell-type scores of technical efficiency (Farrell, 1957). Furthermore, as defined by expressions (8) and (9), scores of technical efficiency computed with respect to the technology of group $h$ will be equal to or higher than those computed relative to the metatechnology.

The metatechnology ratio of group h can then be defined as:

Metatechnology ratio $\operatorname{radial}_{\text {ral }}^{\mathrm{h}}\left[\mathrm{x}, \mathrm{y} ; \mathrm{g}_{\text {radial }}=\left(-\mathrm{x}_{\mathrm{v}}, 0\right)\right]=\frac{\text { Techical efficiency }_{\text {radial }}}{\text { Technical efficiency }}=\frac{\left(1-\delta_{\text {radial }}^{\mathrm{h}}\right)}{\left(1-\delta_{\text {radial }}^{\mathrm{h}}\right)}$

This metatechnology ratio provides a measure of how close the technology of group $h$ is to the metatechnology, assessed in a direction that reduces all variable inputs proportionally. According to O'Donnell et al. $(2008 ; 237)$, this approach provides a suitable decomposition of technical efficiency assessed with respect to the metafrontier (representing the existing state of knowledge), into the product of technical efficiency measured with respect to the frontier of group $\mathrm{h}$ (that represents the state of knowledge and also physical, regulatory and other restrictions faced by units in that group) and the metatechnology ratio for group h (which measures how close the technology of this group is to the joint technology). Formally:

Technical efficiency $_{\text {radial }}=$ Technical efficiency ${ }_{\text {radial }}^{\mathrm{h}} \cdot$ Metatechnology ratio $_{\text {radial }}^{\mathrm{h}}$

Put less technically, this approach allows the decomposition of technical efficiency into managerial efficiency, which assesses performance of decision units in the sample as compared to best practices in their group, and ownership efficiency, which measures the closeness of the technology of group $\mathrm{h}$ to the joint technology. 
Similarly, the input-specific metatechnology ratio for variable input $\mathrm{i}$ and group $\mathrm{h}$ is: ${ }^{10}$

Metatechnology ratio $\operatorname{rat}_{i}^{h}\left\langle x, y ; g_{i}=\left[\left(-x_{v_{i}}, 0\right), 0\right]\right\rangle=\frac{\text { Technical efficiency }_{i}}{\text { Technical efficiency }_{i}^{h}}=\frac{\left(1-\delta_{i}\right)}{\left(1-\delta_{i}^{h}\right)}$

The interpretation of this metatechnology ratio is analogous to that in expression (10) with the difference that now the closeness of group h's technology to the metafrontier is assessed in a direction that only reduces input $i$ without increasing the usage of input $-i$ and maintaining outputs. The decomposition of expression (11) also holds.

\subsubsection{Computation of directional distance functions}

The directional metadistance/distance functions in our analysis have been computed with Data Envelopment Analysis (DEA). This technique is a well-known non-parametric approach to efficiency measurement based on mathematical programming pioneered by Charnes et al. (1978) that has been used in hundreds of empirical papers (Cook \& Seiford, 2009 and Liu et al., 2013 review this literature). By using DEA it is possible to build a technological frontier from data on best observed practices in a sample of decisionmaking units and simultaneously calculate the distance that separates each unit from that frontier in terms of a performance indicator (see Cooper et al., 2007 for details).

Accordingly, the mathematical program required to calculate the directional metadistance function of expression (3), where both labour and operational costs are proportionally reduced, for a decision unit $\mathrm{k}^{\prime}$ in the sample is:

$M \vec{D}_{\text {radial }}^{\mathrm{k}^{\prime}}=$ Maximise $\delta_{\delta_{\text {radial }}^{k^{\prime}}, z^{k^{k}}} \delta_{\text {radial }}^{\mathrm{k}^{\prime}}$

subject to:

$\mathrm{y}_{\mathrm{m}}^{\mathrm{k}^{\prime}} \leq \sum_{\mathrm{k}=1}^{70} \mathrm{z}^{\mathrm{k}} \mathrm{y}_{\mathrm{m}}^{\mathrm{k}}$ $\mathrm{m}=$ water delivered, population served

$\mathrm{x}_{\mathrm{f}}^{\mathrm{k}^{\prime}} \geq \sum_{\mathrm{k}=1}^{70} \mathrm{z}^{\mathrm{k}} \mathrm{x}_{\mathrm{f}}^{\mathrm{k}}$ $\mathrm{f}=$ delivery network

$\left(1-\delta_{\text {radial }}^{k^{\prime}}\right) x_{v_{i}}^{k^{\prime}} \geq \sum_{k=1}^{70} z^{k} x_{v_{i}}^{k} \quad i=$ labour, operational costs

$\mathrm{z}^{\mathrm{k}} \geq 0 \quad \mathrm{k}=1, \ldots, 70$

$\sum_{\mathrm{k}=1}^{70} \mathrm{z}^{\mathrm{k}}=1$

\footnotetext{
10 Technical efficiency with respect to both the metatechnology and the technology of group $\mathrm{h}$
} when only input variable $i$ is reduced can be directly computed from expressions (4) and (7). 
with $\mathrm{z}^{\mathrm{k}}$ representing the weighting of each management unit $\mathrm{k}$ in the sample making up the efficient metafrontier to which unit $\mathrm{k}^{\prime}$ is compared.

Likewise, the DEA-based program needed to compute the directional metadistance function of expression (4) for decision unit $k^{\prime}$ when only variable input $\mathrm{i}$ - either labour or operational costs - is reduced, while maintaining the other variable input -i and the vector of outputs is:

$M \vec{D}_{i}^{k^{\prime}}=$ Maximise $\delta_{\delta_{i}^{k^{\prime}}, z^{k}} \delta_{i}^{k^{\prime}}$

subject to:

$\mathrm{y}_{\mathrm{m}}^{\mathrm{k}^{\prime}} \leq \sum_{\mathrm{k}=1}^{70} \mathrm{z}^{\mathrm{k}} \mathrm{y}_{\mathrm{m}}^{\mathrm{k}} \quad \mathrm{m}=$ water delivered, population served

$\mathrm{x}_{\mathrm{f}}^{\mathrm{k}^{\prime}} \geq \sum_{\mathrm{k}=1}^{70} \mathrm{z}^{\mathrm{k}} \mathrm{x}_{\mathrm{f}}^{\mathrm{k}}$

$\mathrm{f}=$ delivery network

$\left(1-\delta_{\mathrm{i}}^{\mathrm{k}^{\prime}}\right) \mathrm{x}_{\mathrm{v}_{\mathrm{i}}}^{\mathrm{k}^{\prime}} \geq \sum_{\mathrm{k}=1}^{70} \mathrm{z}^{\mathrm{k}} \mathrm{x}_{\mathrm{v}_{\mathrm{i}}^{\mathrm{k}}}^{\mathrm{k}} \quad \mathrm{i} \in \mathrm{n}=$ labour, operational costs; and $\mathrm{i} \notin-\mathrm{i}$

$\mathrm{x}_{\mathrm{v}_{-\mathrm{i}}}^{\mathrm{k}^{\mathrm{j}}} \geq \sum_{\mathrm{k}=1}^{70} \mathrm{z}^{\mathrm{k}} \mathrm{x}_{\mathrm{v}_{-\mathrm{i}}}^{\mathrm{k}} \quad-\mathrm{i} \in \mathrm{n}=$ labour, operational costs

$\mathrm{z}^{\mathrm{k}} \geq 0 \quad \mathrm{k}=1, \ldots, 70$

$\sum_{\mathrm{k}=1}^{70} \mathrm{z}^{\mathrm{k}}=1$

In programs (13) and (14) variable returns to scale have been assumed by restricting the sum of the elements of the intensities vector, i.e., the weightings of decision units in the sample in the composition of the efficient frontier, to be equal to one (Banker et al., 1984). The reason for this choice is that what we want to assess are differences of efficiency due to different managerial capabilities of public and private managers as well as differences between the two production technologies, but not differences due to the scale of operation.

Finally, since formulating the programs to calculate the directional metadistance and distance functions of units in group $h$ requires only a few changes in notation and the substitution of the whole sample of decision units with units in the group $h$, either public or private management, this is left to the reader.

\section{Results and discussion}

Using the methodology described in Section 3.2, we have computed scores of technical efficiency and metafrontier ratios for all decision units in our sample, in both radial and 
input-specific reduction scenarios, with average results shown in Tables 3 and 4, respectively. ${ }^{11}$ Furthermore, differences of metatechnology ratios between public and private decision units have been assessed using conventional Kolmogorov-Smirnov and Mann and Whitney non-parametric tests, in addition to the Simar-Zelenyuk-Li test (Simar \& Zelenyuk, 2006; Li, 1996), and the results are shown in Table 5. Figure 2 represents the Kernel density estimation functions of the metatechnology ratios for public and private management units, providing a graphical illustration of the difference between both distributions.

In the conventional scenario that assesses potential proportional reductions of both variable inputs given the endowment of the fixed input and, also, maintaining outputs, the average for radial efficiency of all decision units in the sample calculated with respect to the metatechnology or joint technology is 0.568 (Table 3). This score suggests that, in such conditions, labour and operational costs could both be proportionally reduced by $43.2 \%$. For public and private units considered separately, averages of radial technical efficiency are 0.576 and 0.568 , respectively, and the difference is not statistically significant at standard confidence levels. ${ }^{12}$ As for managerial efficiency scores, i.e., those computed with respect to the group technologies, averages are 0.669 and 0.682 for public and private decision units, respectively. However, it is important to point out that these scores are not directly comparable to each other because they have been obtained with respect to different technological frontiers, and it is well known that efficiency is a relative concept. Lastly, averages for the metatechnology ratios of public and private units are $0.833^{13}$ and 0.838 , respectively, and they are not statistically different (see Table 5).

The abovementioned results are in line with most studies in this field, and suggest that there is no significant difference in efficiency between public and private management units. Nonetheless, the picture is rather different when performance is evaluated at the

\footnotetext{
11 The exactness of the decomposition of technical efficiency does not hold at the aggregated level due to the use of arithmetic means.

12 Differences in performance with respect to the metatechnology have been assessed using Kolmogorov-Smirnov, Mann and Whitney and Simar-Zelenyuk-Li tests.

13 This means that the efficient level of labour input usage needed to produce a given output vector relative to the joint technology is $83.3 \%$ of the efficient usage relative to the technology of the group of privately managed units.
} 
level of the management of specific production factors, which reinforces the interest of our approach.

In the scenario where only labour input is reduced, technical efficiency averages computed with respect to the metatechnology are 0.402 and 0.480 for public and private decision units, respectively; moreover, the difference is statistically significant pointing to the higher efficiency of private management (see footnote \#10). But what are the reasons for the better performance of private units? On the one hand, managerial efficiency scores for public and private units are 0.598 and 0.613 , respectively. Although, as mentioned above, these scores are not directly comparable to each other, private units seem to be slightly closer to their technological frontier, on average, than public ones are to their technology. On the other hand, and more interestingly, the metatechnology ratios for public and private units average 0.651 and 0.778 , respectively, i.e., the technology of private management units is closer to the metatechnology than the technology of public units; moreover, the difference is statistically significant (see Table 5). Put less technically, the technology of private decision units appears to be more efficient in the management of labour input. ${ }^{14}$

The superiority of the technology used by private units in the management of labour might be due to some regulatory and institutional restrictions faced by public management units. In general, public managers are constrained by more stringent labour regulation which makes it more difficult to fire employees, and they also face higher levels of absenteeism (Meier \& O'Toole, 2011). In addition, local governments, particularly those ruled by left-wing parties, tend to develop policies to promote employment stability (Botero et al., 2004; Emmenegger, 2011), as they consider the political costs of cutting jobs to be extremely high. Furthermore, public workers could also emerge as a lobby with a high negotiating power. Finally, creating overemployment when public services are delivered in-house might also form part of local politicians' rent-seeking strategy (Hart et al., 1997).

\footnotetext{
14 Picazo-Tadeo et al. (2009b) used a methodological approach based on the computation of inputspecific scores of technical efficiency to provide evidence of the superiority of private utilities regarding the management of labour; however, here we go one step further by decomposing technical efficiency into managerial efficiency and ownership efficiency.
} 
Regarding the scenario where only operational costs are reduced, technical efficiency computed with respect to the metatechnology averages 0.493 and 0.505 for public and private decision units, respectively; however, the difference is not statistically significant (see, again, footnote \#10). This outcome is, nonetheless, the consequence of two contrasting results. On the one hand, private managers are operating, on average, closer to their own technological frontier than their public counterparts: average scores of managerial efficiency for public and private units are 0.539 and 0.620 , respectively. On the other hand, however, private technology is found to be less efficient at managing operational costs than the technology of public management units: metatechnology ratios for public and private decision units are 0.920 and 0.806 , respectively, with the difference being statistically significant according to the Kolmogorov-Smirnov and Mann-Whitney tests but not the Simar-Zelenyuk-Li test (see Table 4).

This result is less robust than that obtained in the case of the specific management of labour input and should thus be interpreted with caution. However, several factors could go some way to explaining this. In the first place, cost-sharing activities may take place, especially under in-house public provision. In other words, some operational costs such as administrative costs or energy consumption could be included in the budget item for general municipality expenses, and it would be very difficult to get accurate estimates of the share corresponding to water services. Secondly, it has been shown that there is a tendency to privatise water services operating in more complex environments (González-Gómez et al., 2011), which might imply higher operational costs. For example, some factors that could have an impact on operational costs include the state of conservation of the delivery network, the source of raw water and its quality, and network efficiency.

In order to capture the impact of the abovementioned factors on the probability of opting for publicly managed water delivery services, a probit model has been estimated and the results are shown in Table 6. We have taken as explanatory variables the network losses (measured as the percentage of water losses over distributed water), a labour-population ratio (expressed as workers per 1,000 inhabitants), a dummy variable that takes a value of 1 when an intensive treatment is required to make raw water suitable for drinking, an index of delivery network density (kilometres per 1,000 inhabitants), and finally, the percentage of households not connected to the delivery network. The estimated coefficients show that public management is characterised by higher levels of both network losses 
and the labour-population ratio. In addition, intensive treatment of raw water decreases the chance of the service being publicly managed. These findings are in line with the intuitive interpretation outlined in the previous paragraph.

\section{Summary and conclusions}

Some regulatory changes in developed countries in the late 1970s sought to liberalise economic activity and favoured the entry of private management into the urban water industry. These changes were fuelled by the belief that, far from serving the general interest, public provision led to important inefficiencies in water services provision. Since then, a number of papers have focused on analysing the impact of ownership and organisational forms on water services efficiency, using a range of conceptual and methodological approaches. However, after more than three decades of research, the debate about private participation in the water industry is still ongoing, and existing studies have not provided convincing empirical evidence of private management's superiority to public management. In addition, recent cases of remunicipalisation and growing citizens' movements against new privatisations have further intensified the debate.

In this paper, we revisit the relationship between ownership and performance in urban water services provision. Our main contribution is the use of a fresh approach to assess efficiency in the management of water delivery, based on the use of directional distance functions, metafrontiers and Data Envelopment Analysis. The main advantage of this approach is that it allows us to distinguish between managerial and ownership efficiency at the level of the management of specific inputs.

Furthermore, we focus our analysis on the situation in Spain. Our main result comes from the assessment of efficiency at the level of the management of specific production factors, and suggests the existence of statistically significant differences between the technologies of public and private management units. On the one hand, the technology of private units is found to be more efficient in the management of labour, which might be due to institutional, regulatory and also political restrictions faced by public management units. Conversely, the technology of public units appears to be more efficient in the management of operational costs, perhaps because private units operate in more complex environments, which probably leads to higher operational costs. 
Finally, it is worth mentioning some limitations of our approach that also constitute lines for future research. In order to achieve more precise performance evaluations, it would be interesting to include in the analysis some quality dimensions, such as tap water quality. Likewise, it would be worthwhile extending our methodology to integrate noncontrollable inputs and/or environmental factors into the analysis.

\section{Acknowledgements}

The authors acknowledge the useful comments from the participants in the International Seminar 'European Water Utility Management: Promoting Innovation within the Water Industry and Spreading Knowledge on Relevant and Cutting Edge Water Utility Issues' (Pisa, June 2015), where an earlier version of the manuscript was presented. The financial support of the Spanish Ministry of Economy and Competitiveness (project ECO2012-32189) and the Regional Government of Andalusia (projects P11-SEJ-7039 and P11-SEJ-7294) is also gratefully acknowledged. The usual disclaimer applies.

\section{References}

Banker, R., Charnes, R., Cooper, W. (1984). Some models for estimating technical and scale inefficiencies in Data Envelopment Analysis. Management Science 30, 1078-1092.

Beltrán-Esteve (2013). Assessing technical efficiency in traditional olive grove systems: A directional metadistance function approach. Economía Agraria y Recursos Naturales 13, 53-76.

Beltrán-Esteve, M., Gómez-Limón, J.A., Picazo-Tadeo, A.J., Reig-Martínez, E. (2014). A metafrontier directional distance function approach to assessing eco-efficiency'. Journal of Productivity Analysis 41, 69-83.

Benito, B., Bastida, F., García, J. (2010). Explaining differences in efficiency: An application to Spanish municipalities. Applied Economics 42(4), 515-528.

Berg, S.V., Marques, R.C. (2011). Quantitative studies of water and sanitation utilities: a benchmarking literature survey. Water Policy, 13(5), 591-606.

Bhattacharyya, A., Harris, T.R., Narayanan, R., Raffie, K. (1995a). Specification and estimation of the effect of ownership on the economic efficiency of the water utilities. $R e-$ gional Science and Urban Economics, 25, 759-784.

Bhattacharyya, A., Harris, T.R., Narayanan, R., Raffiee, K. (1995b). Technical efficiency of rural water utilities. Journal of Agricultural and Resource Economics, 20(2), 373-391. 
Bhattacharyya, A., Parker, P., Raffiee, K. (1994). An examination of the effect of ownership on the relative efficiency of public and private water utilities. Land Economics, 70(2), 197-209.

Botero, J.C., Djankov, S., La Porta, R., Lopez-de-Silanes, F., Shleifer, A. (2004). The regulation of labor. Quarterly Journal of Economics 119(4), 1339-1382.

Bruggink, T.H. (1982). Public versus regulated private enterprise in the municipal water industry: A comparison of operating costs. Quarterly Review of Economics and Business, $22,111-125$.

Byrnes, P., Grosskopf, S., Hayes, K. (1986). Efficiency and ownership: Further evidence. Review of Economics and Statistics, 68, 337-341.

Byrnes, J., Crase, L., Dollery, B., Villano, R. (2010). The relative economic efficiency of urban water utilities in regional New South Wales and Victoria. Resource and Energy Economics, 32(3), 439-455.

Carvalho, P., Marques, R.C., Berg, S. (2012). A meta-regression analysis of benchmarking studies on water utilities market structure. Utilities Policy, 21. 40-49.

Chambers, R., Chung, Y., Färe, R. (1998). Profit, directional distance functions and Nerlovian efficiency. Journal of Optimization Theory and Applications 98, 351-364.

Charnes, A., Cooper, W.W., Rhodes, E. (1978). Measuring the efficiency of decision making units. European Journal of Operational Research 2, 429-444.

Cook, W.D., Seiford, L.M. (2009). Data envelopment analysis (DEA) - thirty years on. European Journal of Operational Research 192, 1-17.

Cooper, W.W., Seiford, L.M., Tone, K., 2007. Data Envelopment Analysis. A comprehensive text with models, applications, references and DEA-Solver software. Springer, New York.

Crain, W.M., Zardkoohi, A. (1978). A test of the property-rights theory of the firm: Water utilities in the United States. Journal of Law and Economics, 21, 395-408.

Da Cruz, N.F., Marques, R.C., Romano, G., Guerrini, A. (2012). Measuring the efficiency of water utilities a cross-national comparison between Portugal and Italy. Water Policy 14(5), 841-853.

Donahue, J. (1989). The privatization decision. Public Ends, Private Means, New York.

Emmenegger, P. (2011). Job security regulations in Western democracies: A fuzzy set analysis. European Journal of Political Research 50(3), 336-364.

Estache, A., Rossi, M.A. (2002). How different is the efficiency of public and private water companies in Asia? The World Bank Economic Review, 16(1), 139-148.

Estache, A., Trujillo, L. (2003). Efficiency effects of 'privatization' in Argentina's water and sanitation services. Water Policy, 5(4), 369-380.

Färe, R., Grosskopf, S. (2000). Theory and application of directional distance functions. Journal of Productivity Analysis 13, 93-103. 
Faria, C.R., Souza, G., Moreira, T. (2005). Public versus private water utilities. Empirical evidence for Brazilian companies. Economics Bulletin, 8(2), 1-7.

Feigenbaum, S., Teeples, R. (1983). Public versus private water delivery: A hedonic cost approach. Review of Economics and Statistics, 65, 672-678.

García-Sánchez, I.M. (2006). Efficiency measurement in Spanish local government: The case of municipal water services. Review of Policy Research, 23(2), 355-372.

García-Valiñas, M.A., González-Gómez, F., Picazo-Tadeo, A. (2013). Is the price of water for residential use related to provider ownership? Empirical evidence from Spain. $\underline{\text { Uti- }}$ lities Policy 24, 59-69.

González-Gómez, F., García-Rubio, M.A., Alcalá-Olid, F., Ortega-Díaz, M.I. (2013). Outsourcing and efficiency in the management of rural water services. Water Resources Management 27(3), 731-747.

González-Gómez, F., Picazo-Tadeo, A.J., Guardiola, J. (2011). Why do local governments privatise the provision of water services? Empirical evidence from Spain. Public Administration 89(2), 471-492.

Guerrini, A., Romano, G., Campedelli, B. (2011). Factors affecting the performance of water utility companies. International Journal of Public Sector Management 24(6), 543566.

Hart, O., Shleifer, A., Vishny, R. (1997). The proper scope of government: Theory and an application to prisons. Quarterly Journal of Economics, 112(4), 1127-1161.

Hon, L.Y., Boon, T.H., Lee, C. (2014). Productivity, efficiency and privatization in the Malaysian water industry. Journal of Southeast Asian Economies, 31(2), 292-312.

Kirkpatrick, C., Parker, D., Zhang, Y.F. (2006). An empirical analysis of state and private sector provision of water services in Africa. The World Bank Economic Review, 20(1), 143-163.

Lambert, D.K., Dichev, D., Raffiee, K. (1993). Ownership and sources of inefficiency in the provision of water services. Water Resources Research, 29(6), 1573-1578.

Lannier, A., Porcher, S. (2014). Efficiency in the public and private French water utilities: prospects for benchmarking. Applied Economics, 46(5), 556-572.

Li, Q. (1996). Nonparametric testing of closeness between two unknown distribution functions. Econometric Reviews, 15(3), 261-274.

Liu, J., Lu, L., Lu, W., Lin, B. (2013). A survey of DEA applications. Omega 41, 893-902.

Lo Storto, C. (2013). Are public-private partnerships a source of greater efficiency in water supply? Results of a non-parametric performance analysis relating to the Italian industry. Water 5(4), 2058-2079.

Lobina, E., Hall, D. (2000). Public sector alternatives to water supply and sewerage privatization. Case Studies. International Journal of Water Resources Development 16(1), 3555. 
Mann, P.C., Mikesell, J.L. (1976). Ownership and water system operation, Water Resources Bulletin 12(5), 995-1004.

Meier, K.J., O'Toole, L.J. (2011). Comparing public and private management: Theoretical expectations. Journal of Public Administration Research and Theory 21, 283-299.

Morgan, W.D. (1977). Investor owned vs. publicly owned water agencies: An evaluation of the property rights theory of the firm. Water Resources Bulletin, 13(4), 775-781.

Niskanen, W.A. (1971). Bureaucracy and representative government. Chicago: Aldine.

O'Donnell, C., Rao, D., Battese, G. (2008). Metafrontier frameworks for the study of firmlevel efficiencies and technology ratios. Empirical Economics 34(2), 231-255.

OCDE (2003). Social issues in the provision and pricing of water services. OECD Publishing, Paris.

Peda, P., Grossi, G., Liik, M. (2013). Do ownership and size affect the performance of water utilities. Evidence from Estonian municipalities. Journal of Management and Government, 17(2), 237-259.

Pérard, E. (2009). Water supply: Public or private? An approach based on cost of funds, transaction costs, efficiency and political costs. Policy and Society, 27, 193-219.

Picazo-Tadeo, A., Sáez-Fernández, F.J., González-Gómez, F., (2008). Does service quality matter in measuring the performance of water utilities. Utilities Policy 16, 30-38.

Picazo-Tadeo, A.J., Castillo, J., Beltrán-Esteve, M. (2014). An intertemporal approach to measuring environmental performance with directional distance functions: greenhouse gas emissions in the European Union. Ecological Economics 100, 173-182.

Picazo-Tadeo, A.J., González-Gómez, F., Guardiola, J., Ruiz-Villaverde, A. (2012). Do ideological and political motives really matter in the public choice of local services management? Evidence from urban water services in Spain. Public Choice 151, 215228.

Picazo-Tadeo, A.J., González-Gómez, F., Sáez-Fernández, F.J. (2009a). Accounting for operating environments in measuring water utilities' managerial efficiency. The Service Industries Journal, 29(6), 761-773.

Picazo-Tadeo, A.J., Sáez-Fernandez, F.J., Gonzalez Gomez, F. (2009b). The role of environmental factors in water utilities' technical efficiency. Applied Economics, 41(5), 615628.

Pigou, A. (1932). The economics of welfare. Macmillan \& Co., London.

Romano, G., Guerrini, A. (2011). Measuring and comparing the efficiency of water utility companies: A data envelopment analysis approach. Utilities Policy 19, 202-209.

Romano, G., Guerrini, A., Vernizzi, S. (2013). Ownership, investment policies and funding choices of Italian water utilities: An empirical analysis. Water Resources Management, 27(9), 3409-3419.

Saal D.S., Parker D., Weyman-Jones J.G. (2007) Determining the contribution of technical change, efficiency change and scale change to productivity growth in the privatized 
English and Welsh water and sewerage industry: 1985-2000. Journal of Productivity Analysis, 28(1), 127-139.

Saal, D.S., Parker, D. (2001). Productivity and price performance in the privatized water and sewerage companies of England and Wales. Journal of Regulatory Economics, 20(1), $61-90$.

Sabbioni, G. (2008). Efficiency in the Brazilian sanitation sector. Utilities Policy, 16, 11-20.

Sáez-Fernández, F., Picazo-Tadeo, A.J., Llorca-Rodríguez, C. (2012). Do labour societies perform differently to cooperatives? Evidence from the Spanish building industry. Annals of Public and Cooperative Economics 83(1), 61-81.

Saussier, S., Ménard, C. (2000). Contractual choice and performance the case of water supply in France. Revue d'Économie Industrielle, Programme National Persée, 92(1), 385404.

Shephard, W. (1970). Theory of cost and production functions. Princeton University Press, Princeton.

Simar, L., Zelenyuk, V. (2006). On testing equality of distributions of technical efficiency scores. Econometric Reviews, 25(4), 497-522.

Zschille, M., Walter, M. (2012). The performance of German water utilities: A (semi)parametric analysis. Applied Economics, 44(29), 3749-3764. 


\section{Tables and figures}

Table 1. Public versus private management of water services: Some empirical studies.

\begin{tabular}{|c|c|c|}
\hline $\begin{array}{l}\text { Superiority of public } \\
\text { management }\end{array}$ & $\begin{array}{c}\text { Superiority of private } \\
\text { management }\end{array}$ & $\begin{array}{c}\text { No significant difference or } \\
\text { inconclusive }\end{array}$ \\
\hline Mann \& Mikesell (1976) & Morgan (1977) & Feigenbaum \& Teeples (1983) \\
\hline Bruggink (1982) & Crain \& Zardkoohi (1978) & Byrnes et al. (1986) \\
\hline Lambert et al. (1993) & Bhattacharyya et al. (1995b) & Saussier \& Menard (2000) \\
\hline Bhattacharyya et al. (1994) & Estache \& Kouassi (2002) & Estache \& Rossi (2002) \\
\hline Bhattacharyya et al. (1995a) & Faria et al. (2005) & Kirkpatrick et al. (2006) \\
\hline Lobina \& Hall (2000) & Picazo-Tadeo et al. (2009a;b) & García-Sánchez (2006) \\
\hline Benito et al. (2010) & Lo Storto (2013) & Sabbioni (2008) \\
\hline Romano \& Guerrini (2011) & & Zschille \& Walter (2012) \\
\hline Guerrini et al. (2011) & & Peda et al. (2013) \\
\hline Da Cruz et al. (2012) & & González-Gómez et al. (2013) \\
\hline Romano et al. (2013) & & Hon et al. (2014) \\
\hline Lannier \& Porcher (2014) & & \\
\hline
\end{tabular}

Table 2. Sample descriptive statistics

\begin{tabular}{lrrrrr}
\cline { 2 - 5 } & Measurement unit & Mean & $\begin{array}{l}\text { Standard } \\
\text { deviation }\end{array}$ & Maximum & Minimum \\
\hline Public management & & & & \\
Water delivered & Thousands of m ${ }^{3}$ & 510.4 & 526,6 & $2,365.3$ & 55.0 \\
Population served & Thousands & 7.4 & 7.2 & 25.3 & 1,1 \\
Labour & Full-time workers & 4.5 & 2.7 & 11.0 & 0.5 \\
Operational costs & Thousands of $€$ & 415.5 & 532.2 & $2,351.9$ & 44.5 \\
Distribution network & Kilometres & 43.6 & 33.6 & 163.7 & 7.7 \\
& & & & & \\
Private management & & & & & \\
Water delivered & Thousands of m ${ }^{3}$ & $1,561.0$ & $1,120,0$ & $3,475.5$ & 113.4 \\
Population served & Thousands & 21.2 & 13.9 & 43.8 & 1.6 \\
Labour & Full-time workers & 12.6 & 10.5 & 43.0 & 1.6 \\
Operational costs & Thousands of $€$ & $1,414.9$ & 986.9 & $3,767.9$ & 74.1 \\
Distribution network & Kilometres & 157.2 & 230.0 & $1,330.8$ & 24.1 \\
\hline
\end{tabular}


Table 3. Estimates of radial technical efficiency

\begin{tabular}{lcr}
\cline { 2 - 3 } & Mean & $\begin{array}{c}\text { Standard } \\
\text { deviation }\end{array}$ \\
\hline Technical efficiency with respect to the metafrontier & 0.568 & 0.282 \\
Public management & 0.576 & 0.251 \\
Private management & 0.568 & 0.317 \\
Technical efficiency with respect to the group frontier & & \\
(managerial efficiency) & & \\
Public management & 0.669 & 0.229 \\
Private management & 0.682 & 0.312 \\
Metatechnology ratio (ownership efficiency) & & \\
Public management & 0.833 & 0.185 \\
Private management & 0.838 & 0.199 \\
\hline
\end{tabular}

Table 4. Estimates of input-specific technical efficiency

\begin{tabular}{|c|c|c|c|c|}
\hline & \\
\hline & & \multirow{2}{*}{$\begin{array}{c}\text { Labour } \\
\begin{array}{l}\text { Standard } \\
\text { deviation }\end{array}\end{array}$} & \multicolumn{2}{|c|}{ Operational costs } \\
\hline & Mean & & Mean & $\begin{array}{l}\text { Standard } \\
\text { deviation }\end{array}$ \\
\hline \multicolumn{5}{|c|}{ Technical efficiency with respect to the } \\
\hline Public management & 0.402 & 0.292 & 0.493 & 0.294 \\
\hline Private management & 0.480 & 0.358 & 0.505 & 0.361 \\
\hline \multicolumn{5}{|c|}{$\begin{array}{l}\text { Technical efficiency with respect to the } \\
\text { group frontier (managerial efficiency) }\end{array}$} \\
\hline Public management & 0.598 & 0.264 & 0.539 & 0.305 \\
\hline Private management & 0.613 & 0.358 & 0.620 & 0.373 \\
\hline \multicolumn{5}{|c|}{$\begin{array}{l}\text { Metatechnology ratio (ownership } \\
\text { efficiency) }\end{array}$} \\
\hline Public management & 0.651 & 0.220 & 0.920 & 0.134 \\
\hline Private management & 0.778 & 0.259 & 0.806 & 0.214 \\
\hline
\end{tabular}


Table 5. Differences in the metatechnology ratio: Public versus private management

\begin{tabular}{|c|c|c|c|}
\hline & \\
\hline & $\begin{array}{l}\text { Kolmogorov- } \\
\text { Smirnov test }{ }^{a}\end{array}$ & $\begin{array}{r}\text { Mann-Whitney } \\
\text { test }^{b}\end{array}$ & $\begin{array}{r}\text { Simar-Zelenyuk-Li } \\
\text { test }{ }^{c}\end{array}$ \\
\hline & $\begin{array}{r}\text { KS-statistic } \\
(p \text {-value })^{d}\end{array}$ & $\begin{array}{c}\text { Z-statistic } \\
(p \text {-value })^{e}\end{array}$ & $\begin{array}{c}\text { Li-statistic } \\
(p \text {-value } f\end{array}$ \\
\hline Radial technical efficiency & $0.117(0.937)$ & $0.445(0.656)$ & $-0.909(0.818)$ \\
\hline \multicolumn{4}{|c|}{ Input-specific technical efficiency } \\
\hline Labour & $0.346(0.021)^{* *}$ & $2.442(0.014)^{\star *}$ & $2.989(0.001)^{* * *}$ \\
\hline Operational costs & $0.322(0.039)^{* *}$ & $-2.289(0.022)^{* *}$ & $0.729(0.232)$ \\
\hline
\end{tabular}

${ }^{*},{ }^{* *}$ and ${ }^{* * * *}$ stands for statistical significance at 10, 5 and 1 per cent, respectively.

${ }^{a}$ The null hypothesis is that the distribution of the two samples is the same.

${ }^{b}$ The null hypothesis is that the two samples are drawn from the same population.

c The null hypothesis is that the two samples have the same probability distribution function.

${ }^{d}$ Exact $p$-values are provided.

e Statistics are adjusted for ties.

$f$ Original estimates of the metatechnology ratio have been smoothed using Algorithm II in Simar and Zelenyuk (2006).

Table 6. Public management: key-factors

\begin{tabular}{cc}
\hline $\begin{array}{c}\text { Estimated } \\
\text { coefficient }\end{array}$ & Z-statistic (p-value) \\
\hline 0.079 & $3.32(0.001)^{* * *}$ \\
0.795 & $1.69(0.090)^{*}$ \\
-0.041 & $-0.84(0.398)$ \\
-0.818 & $-1.81(0.070)^{*}$ \\
-0.026 & $-0.74(0.460)$ \\
-2.515 & $-3.35(0.001)^{* * *}$ \\
\multicolumn{3}{c}{70} \\
$-32.662(31.49)^{* * *}$ \\
\multicolumn{2}{c}{0.325}
\end{tabular}

* , and ${ }^{* * *}$ stands for statistical significance at 10,5 and 1 per cent, respectively. 
Figure 1. Metatechnology, group technologies and metatechnology ratios.

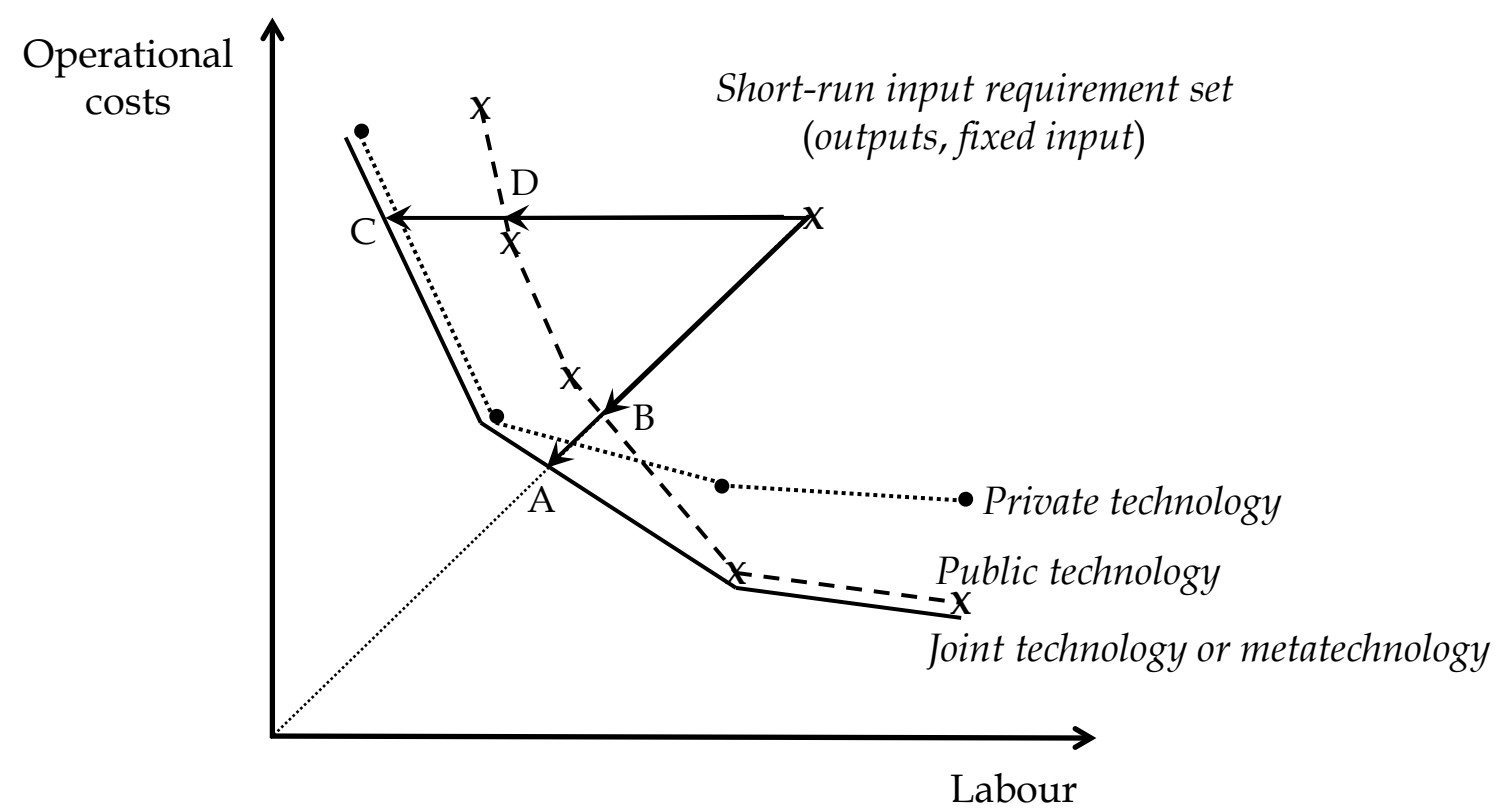


Figure 2. Kernel density estimation functions of metatechnology ratios: public (continuous line) versus private (dashed line) management.

\section{Radial}

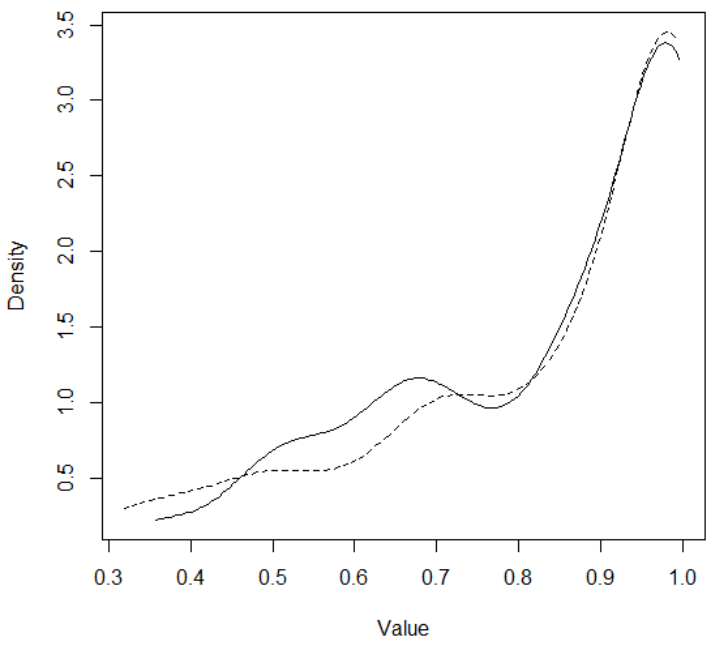

Labour specific

Operational costs specific
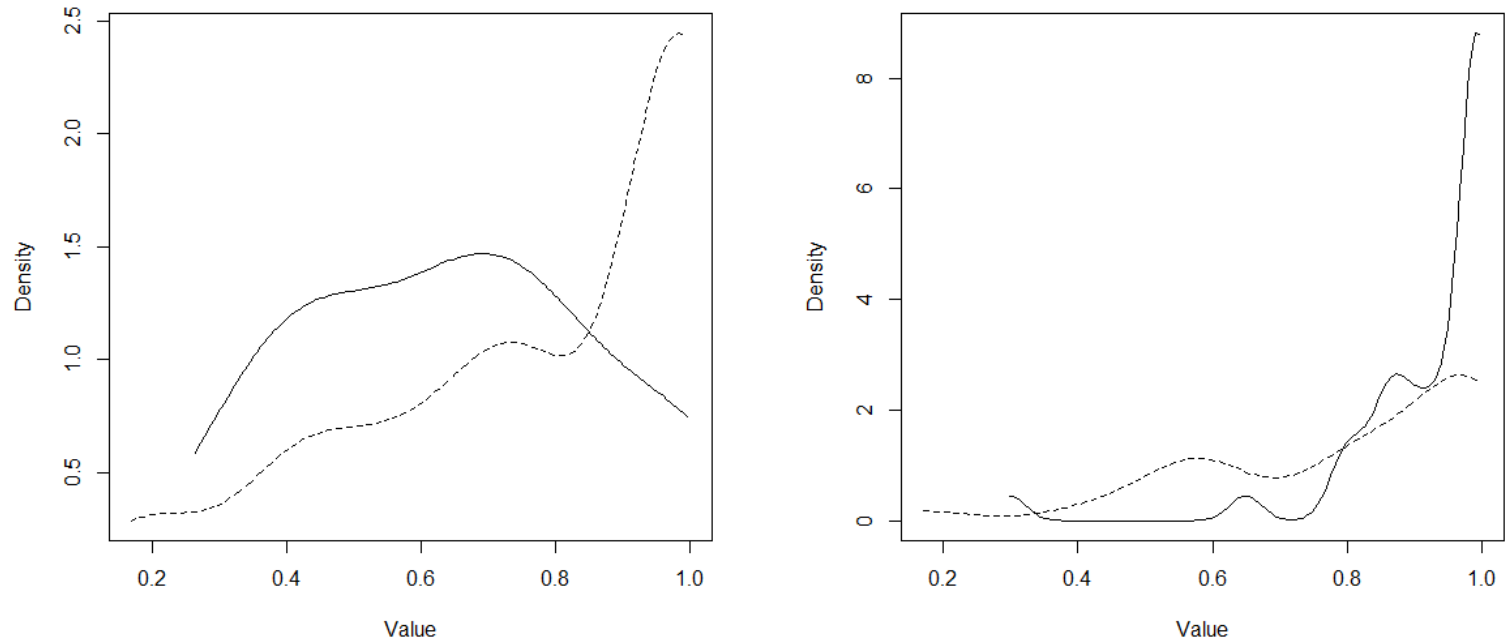